\title{
Studying the effect of the genotypes of the prolactin gene (PRL) on the productive performance of Holstein cows
}

\author{
${ }^{1}$ MAUJ S. Harbeya,${ }^{2}$ ABDALLAH H. SALM \\ ${ }^{1,2}$ Collage of agriculture - Thi_Qar University \\ ${ }^{1}$ Email: Wavesmeme@gmail.com \\ ${ }^{2}$ Email:_Abdallah@utq.edu.iq
}

\begin{abstract}
:
The study was conducted at Taj Al-Nahrain station in Al-Diwaniyah Governorate, which is $200 \mathrm{~km}$ from the center of Dhi Qar Governorate. For the period from 10/15/2021 to 4/15/2021, 85 Holstein cows imported from Germany were used in this experiment, and they were selected from among 700 cows in the station, all of which are in the third production cycle. As for the laboratory part of the study, it was conducted in the laboratories of the Department of Life Sciences at the College of Science / Dhi Qar University for the purpose of separating the genetic material (DNA), conducting polymerase chain reaction and electrophoresis, and identifying genetic mutations in the studied genetic segment on the prolactin gene, The animals in the station were fed according to the season and year in terms of the availability of feed and the percentage of costs involved in raising cows, as well as depending on the general state of cow productivity. But in general, it is provided with green fodder, which includes yoghurt, barley, corn stalks, and a percentage of both dry feed (hay and hay) and concentrated feed (barley, bran and cake) according to what is available from them, as well as limestone and table salt. The data on milk production were collected from the station records, where the milk production was recorded weekly for the morning circuit and the evening circuit by the station, and the milk components were analyzed in the Abu Ghraib Dairy Company / Research and Development Division by a Milk Analyzer, and $3 \mathrm{ml}$ of blood was collected from a vein The udder of each cow was given by medical syringes with a capacity of $5 \mathrm{ml}$, suitable for the size of the animal's vein, and placed in collection tubes containing an anticoagulant substance (K2 EDTA) and transferred in a cooler box for freezing at a temperature of $-18^{\circ} \mathrm{C}$ until the time of extraction. From the results obtained from this study, it can be concluded that the mutation C83T changed the code of the amino acid histidine to the amino acid Tyrosine, which had a significant effect on the characteristics of daily and total milk production, while the mutation G168C changed the amino acid arginine to the amino acid Proline, which was significantly reflected on the traits of persistence. In milk production, the length of the milk season and the proportion of milk protein, most of the average traits for cows in the third season of production appeared higher than the general averages compared to other studies, and most of the simple correlation coefficients between the study traits were high and significant.
\end{abstract}

\section{Keywords: productive traits, prolactin, Holstein cows.}

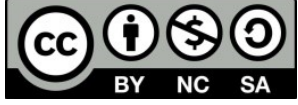




\section{INTRODUCTION}

Breeding cows is one of the most important elements of animal production in Iraq and the world, as it is an important part of the total economic wealth of many countries. The interest in raising and improving the productivity of these animals is one of the important aspects to maximize the economic return. (Al-Anbari and et al, 2005. Milk is a major natural food substance that contains many elements necessary for the growth and development of living organisms. Cows rank first in the world in the production of milk from among the animals, with $90 \%$ of the total production from the farm (Al-Khazraji \& Hormuz 2014). The productive characteristics are of great importance in the projects of milk cows, as they represent the main resource for the economic return in these projects, as many studies have been conducted in Iraq regarding the productive performance of Holstein cows for the characteristics of milk production. With the advent of the new millennium, the millennium of scientific progress and the emergence of various branches of biological sciences, among them the tremendous progress in molecular genetics, which led to the knowledge of the genetic map and the determination of the genome structure of humans, which also required progress in knowledge of the genome structure of both animals and plants. The prolactin hormone (PRL) is considered One of the most diverse pituitary hormones in terms of biological functions and has multiple effects on the mammary gland, Including its growth and development, the synthesis of milk and the maintenance of milk secretion. The PRL gene is a potential genetic marker (and genetic name) for production traits in dairy cows (Brym et al., 2005). Due to the lack of this type of studies, especially genetics in Iraq, this study aimed to reveal the allelic repetition of the genotypes of the mutations resulting from the studied genetic segment of the prolactin gene PRL and to study the relationship of these structures to the productive performance of Holstein cows, especially milk components, as well as studying the general averages between traits.

\section{MATERIALS AND METHODS}

The study was conducted at Taj Al-Nahrain station in Al-Diwaniyah Governorate, which is $200 \mathrm{~km}$ from the center of Dhi Qar Governorate. For the period from 10/15/2021 to 4/15/2021, 85 Holstein cows imported from Germany were used in this experiment, and they were selected from among 700 cows in the station, all of which are in the third production cycle. In addition to the laboratory part, it was conducted in the laboratories of the Department of Life Sciences at the College of Science / University of Dhi Qar for the purpose of separating the genetic material (DNA), conducting polymerase chain reaction and electrophoresis and identifying genetic mutations in the studied genetic segment on the prolactin gene, and the following are the most important results obtained. From the results of the nucleotide sequencing study on the 156 base pair gene segment, four point mutations were detected in the non-coding region (intron 3) of the prolactin gene in the studied cow sample. 


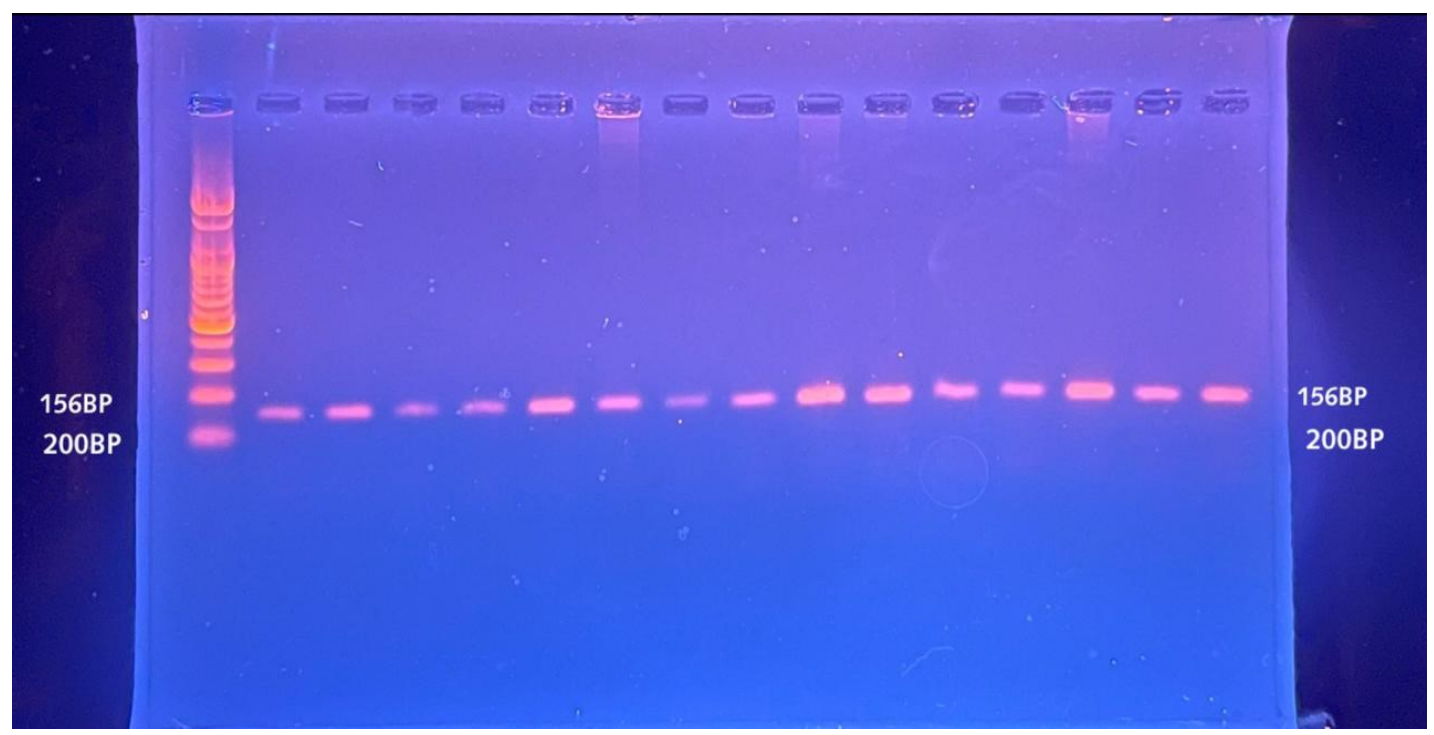

Figure 4-1: PCR product of the prolactin gene (PRL).

Four mutations were obtained, the first of which is G79C, which is with two genetic structures only (GG and GC), and it is of the silent type (silent), as there was no change in the amino acid Leucine, and the second is C83T. This mutation appeared as in the previous one with two genetic structures, namely wild CC and hybrid CT It differed from it in that it was a missense mutation, which led to a change in the code of the resulting amino acid to be Tyrosine instead of Histidine. The third mutation, A92T, showed that this mutation at site 92 of the studied genetic segment of the prolactin gene appeared with two genetic structures, AA and AT and it was a missense mutation by changing the code for producing the amino acid Threonine to Serine. And the last mutation G168C that this mutation worked to change the code that produces the amino acid arginine to the code that produces the amino acid Proline, which indicates that it is a mutation of the Missense type, and it was also found that it appeared with only two genetic structures (GG and GC).

\section{RESULTS AND DISCUSSION}

The results of the study of the nucleotide sequence of the studied segment of the prolactin gene and its relationship with the productive traits:

From the results of the nucleotide sequencing study on the 156 base pair gene segment, four point mutations were detected in the non-coding region (intron 3) of the prolactin gene in the studied cow sample.

\section{1: The G79C mutation:}

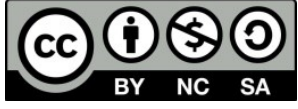


It has only two genetic compositions (GG and GC), and it is of the silent mutation type, as there was no change in the amino acid Leucine (Fig. 4-2).

Bos taurus prolactin (PRL) mRNA, partial cds Sequence ID: MH477634.1Length: 252Number of Matches: 1

Range 1: 71 to 220 GenBankGraphics vext Matcherexious Match

\begin{tabular}{|l|l|l|l|l|}
\hline $\begin{array}{l}\text { Range 1: 71 to 220GenBankGraphics } \\
\text { Score }\end{array}$ & Expect & Identities & Gaps & Strand \\
\hline $\mathbf{2 5 3}$ bits(280) & $2 \mathrm{e}-66$ & $146 / 150(97 \%)$ & $0 / 150(0 \%)$ & Plus/Plus \\
\hline
\end{tabular}

Query 1 GACCстCTCTATCACCTAGTCACCGAGGTGCGGGGTATGAAAGGAGCCCCAGATGCTATC 60

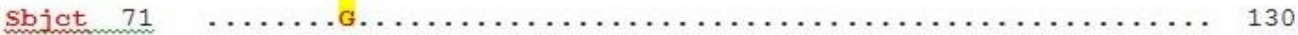

Figure 4-2: The location of the G79C mutation in the studied segment of the prolactin gene

It is clear from Table (1)that the significant effect of this mutation has disappeared among the characteristics of the studied milk components, despite the arithmetic superiority of the GC genotype in all these traits except for the characteristic of the percentage of fat, in which the GG genotype exceeded by 3.43\% compared to $3.42 \%$ for the GC genotype. This result partially agrees with the findings of Bryn and colleagues (2005) in the absence of significant differences between the genotypes of the prolactin gene in the proportion of milk protein in two different genetic groups, as well as Alibanah and colleagues (2007) for the same trait in the breed of Russian red cows.

Table 1: Effect of the genotypes of the G79C mutation on the characteristics of milk components

\begin{tabular}{|l|c|c|c|c|c|c|c|}
\hline $\begin{array}{c}\text { boom } \\
\text { G/C }\end{array}$ & $\begin{array}{c}\text { the } \\
\text { number }\end{array}$ & fat\% & $\begin{array}{c}\text { Non-fat } \\
\text { solids\% }\end{array}$ & $\begin{array}{c}\text { Density } \\
\mathrm{g} / \mathrm{cm} 3\end{array}$ & $\begin{array}{c}\text { Protein } \\
\%\end{array}$ & $\begin{array}{c}\text { Lactose } \\
\%\end{array}$ & $\begin{array}{c}\text { Freezing } \\
\text { point(m0) }\end{array}$ \\
\hline GG & 35 & $\begin{array}{c}3.436 \\
\pm 0.029\end{array}$ & $\begin{array}{c}7.392 \\
\pm 0.059\end{array}$ & $\begin{array}{c}26.475 \\
\pm 0.268\end{array}$ & $\begin{array}{c}2.632 \\
\pm 0.017\end{array}$ & $\begin{array}{c}3.927 \\
\pm 0.076\end{array}$ & $\begin{array}{c}0.670- \\
\pm 0.011\end{array}$ \\
\hline GC & 15 & 3.425 & 7.462 & 26.78 & 2.662 & 4.018 & $0.699-$ \\
& & \pm 0.040 & \pm 0.091 & \pm 0.374 & \pm 0.031 & \pm 0.137 & \pm 0.020 \\
\hline
\end{tabular}

\section{2:C83T. mutation}

This mutation appeared as in the previous one with two genetic structures, wild CC and hybrid CT, but it differed from it as a missense mutation, which led to a change in the code of the resulting amino acid to be Tyrosine instead of Histidine (Fig. 44). 


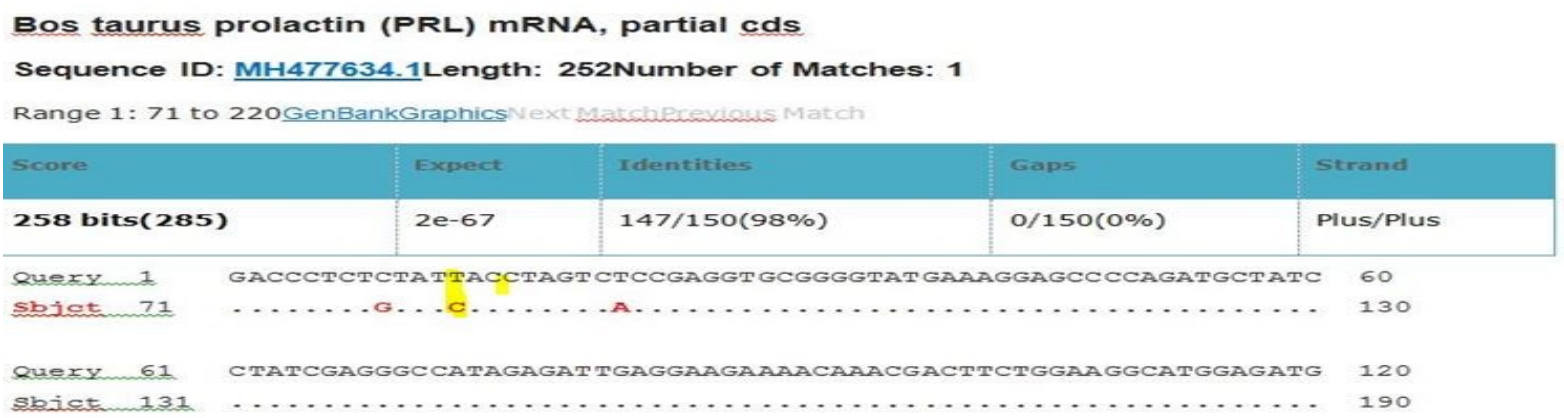

Figure 4-4: The C83T mutation site in the studied segment of the prolactin gene

The C83T mutation did not have any significant effect on the characteristics of milk components in the sample of Holstein cows under study, despite the mathematical superiority of the CT genotype in four of them (fat percentage, non-fat solids, density, and degree of freezing) and the mathematical superiority of CC genotype in the other two traits (protein percentage, percentage of lactose in milk) (Table 4-6). This result differed with what was obtained by Bryn and colleagues (2005) with the superiority of the GG genotype significantly $(\mathrm{P} \leq 0.05)$ and its higher mean in the percentage of milk fat compared to the other two genotypes (AA and AG). Our results are in agreement with Bryn et al. (2005) and Alibanah et al. (2007) for the proportion of milk protein.

Table 2: The effect of the genotypes of the C83T mutation on the characteristics of milk components

\begin{tabular}{|c|c|c|c|c|c|c|c|}
\hline $\begin{array}{c}\text { boom } \\
\mathrm{C} / \mathrm{T}\end{array}$ & $\begin{array}{c}\text { the } \\
\text { number }\end{array}$ & fat $\%$ & $\begin{array}{c}\text { Non-fat } \\
\text { solids } \%\end{array}$ & $\begin{array}{c}\text { Density } \\
\mathrm{g} / \mathrm{cm} 3\end{array}$ & $\begin{array}{c}\text { Protein } \\
\%\end{array}$ & $\begin{array}{c}\text { Lactose } \\
\%\end{array}$ & $\begin{array}{c}\text { Freezing } \\
\text { point }(\mathrm{m} 0)\end{array}$ \\
\hline $\mathrm{CC}$ & 40 & $\begin{array}{c}3.430 \\
\pm 0.026\end{array}$ & $\begin{array}{c}7.404 \\
\pm 0.056\end{array}$ & $\begin{array}{c}26.484 \\
\pm 0.247\end{array}$ & $\begin{array}{c}2.641 \\
\pm 0.016\end{array}$ & $\begin{array}{c}3.959 \\
\pm 0.068\end{array}$ & $\begin{array}{c}0.669- \\
\pm 0.011\end{array}$ \\
\hline $\mathrm{CT}$ & 10 & $\begin{array}{c}3.446 \\
\pm 0.056\end{array}$ & $\begin{array}{c}7.447 \\
\pm 0.104\end{array}$ & $\begin{array}{c}26.890 \\
\pm 0.459\end{array}$ & $\begin{array}{c}2.638 \\
\pm 0.039\end{array}$ & $\begin{array}{c}3.933 \\
\pm 0.201\end{array}$ & $\begin{array}{c}0.71800- \\
\pm 0.023\end{array}$ \\
\hline
\end{tabular}

\section{3: A92T. mutation}

It was found that this mutation at site 92 of the studied genetic segment of the prolactin gene appeared with two genetic structures, AA and AT (Figure 4-5) and was a missense mutation by changing the code for producing the amino acid Threonine to the amino acid Serine. 


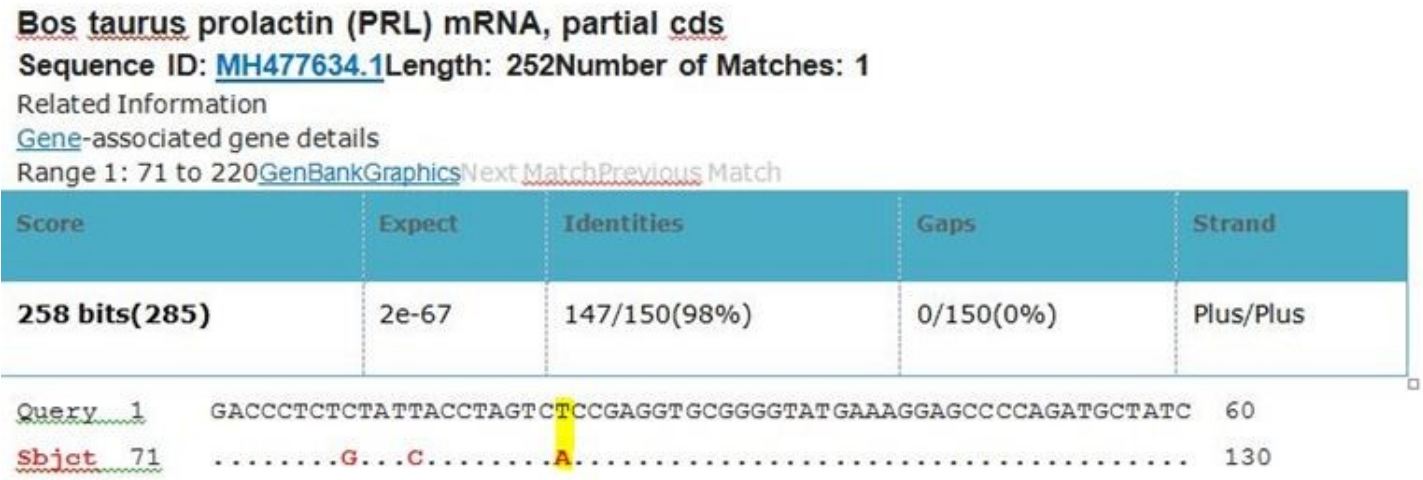

Figure 4-5: The location of the A92T mutation in the studied segment of the prolactin gene

The results of the statistical analysis of the characteristics of milk components were similar to what was found in the characteristics of milk production in terms of the insignificance of the effect of the genotypes resulting from the A92T mutation on the characteristics of the milk components, as well as in terms of the mathematical superiority of the AT genotype in all the characteristics of the studied milk components compared to the other composition (AT).

Table 3: Effect of the genotypes of the A92T mutation on the characteristics of milk components

\begin{tabular}{|c|c|c|c|c|c|c|c|}
\hline $\begin{array}{c}\text { boom } \\
\text { A/T }\end{array}$ & $\begin{array}{c}\text { the } \\
\text { number }\end{array}$ & fat\% & $\begin{array}{c}\text { Non-fat } \\
\text { solids\% }\end{array}$ & $\begin{array}{c}\text { Density } \\
\mathrm{g} / \mathrm{cm} 3\end{array}$ & $\begin{array}{c}\text { Protein } \\
\%\end{array}$ & Lactose \% & $\begin{array}{c}\text { Freezing } \\
\text { point(m0) }\end{array}$ \\
\hline AA & 42 & $\begin{array}{c}3.430 \\
\pm 0.025\end{array}$ & $\begin{array}{c}7.418 \\
\pm 0.057\end{array}$ & $\begin{array}{c}26.522 \\
\pm 0.244\end{array}$ & $\begin{array}{c}2.641 \\
\pm 0.016\end{array}$ & $\begin{array}{c}2.638 \\
\pm 0.016\end{array}$ & $\begin{array}{c}0.672- \\
\pm 0.011\end{array}$ \\
\hline AT & 8 & 3.431 & 7.443 & 27.188 & 2.677 & 3.912 & $0.707-$ \\
& & \pm 0.068 & \pm 0.086 & \pm 0.293 & \pm 0.036 & \pm 0.249 & \pm 0.028 \\
\hline
\end{tabular}

\section{4: G168C. mutation:}

According to the results of genetic analysis of the sequence of nitrogenous bases for the studied plot, it was found that this mutation changed the code that produces the amino acid Arginine to the code that produces the amino acid Proline, which indicates that it is a mutation of the Missense type. 4-10). 


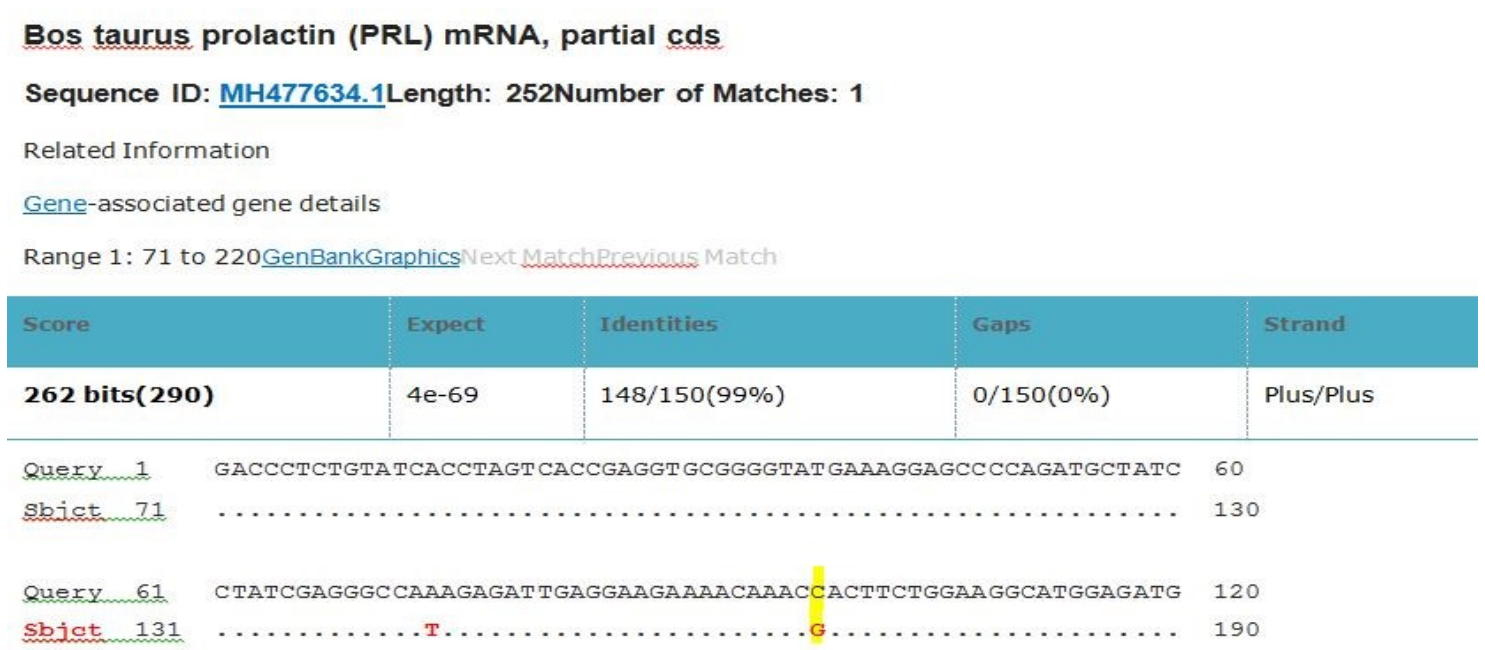

Figure 4-6: The location of the mutation G168C in the studied segment of the prolactin gene

In the characteristics of milk components in Holstein cows, the percentage of protein was uniquely affected by the genotype $(\mathrm{P} \leq 0.05)$ of the $\mathrm{G} 168 \mathrm{C}$ mutation in the prolactin gene, with the superiority of the GG genotype $(\mathrm{P} \leq 0.05)$ by $2.66 \%$ compared to $2.55 \%$ in the GC genotype. While we did not notice a significant effect of the above mutation on other characteristics of milk components, which included each of the percentage of fat, non-fat solids, density, protein percentage and degree of freezing (Table 4-12). It was affected by the genotype of the prolactin gene, and that the GG genotype was significantly $(\mathrm{P} \leq 0.01)$ superior to the genotypes AA and AG, while it agreed with Bryn and colleagues (2005) and Alibanh and colleagues (2007) in the absence of a significant effect of the genotype of the prolactin gene on the characteristic of the proportion of milk protein.

Table 4: Effect of the genotypes of the G168C mutation on the characteristics of milk components

\begin{tabular}{|c|c|c|c|c|c|c|c|}
\hline $\begin{array}{c}\text { boom } \\
\text { G/C }\end{array}$ & $\begin{array}{c}\text { the } \\
\text { number }\end{array}$ & fat $\%$ & $\begin{array}{c}\text { Non-fat } \\
\text { solids } \%\end{array}$ & $\begin{array}{c}\text { Density } \\
\text { g/cm } 3\end{array}$ & $\begin{array}{c}\text { Protein } \\
\%\end{array}$ & $\begin{array}{c}\text { Lactose } \\
\%\end{array}$ & $\begin{array}{c}\text { Freezing } \\
\text { point }(\mathrm{m} 0)\end{array}$ \\
\hline GG & $\mathbf{4 1}$ & $\begin{array}{c} \pm \mathbf{0 . 0 2 7} \\
\mathbf{3 . 4 2 6} \mathbf{A}\end{array}$ & $\begin{array}{c}\mathbf{7 . 4 5 0} \\
\mathbf{A} \pm \mathbf{0 . 0 4 6}\end{array}$ & $\begin{array}{c}\mathbf{2 6 . 7 2 9} \mathbf{A} \\
\pm \mathbf{0 . 2 2 0}\end{array}$ & $\begin{array}{c}\mathbf{2 . 6 6 1} \\
\mathbf{A} \pm \mathbf{0 . 0 1 5}\end{array}$ & $\begin{array}{c}\mathbf{3 . 9 9 5} \\
\mathbf{A} \pm \mathbf{0 . 0 6 9}\end{array}$ & $\begin{array}{c}\mathbf{0 . 6 7 4 -} \\
\mathbf{A} \pm \mathbf{0 . 0 1 2}\end{array}$ \\
\hline GC & $\mathbf{9}$ & $\mathbf{A ~ 3 . 4 5 9}$ & $\mathbf{7 . 2 5 8}$ & $\mathbf{2 5 . 8 9 4}$ & $\mathbf{2 . 5 5 8}$ & $\mathbf{3 . 7 8 2}$ & $\mathbf{0 . 6 9 8}-$ \\
& & $\mathbf{0 . 0 4 7} \pm$ & $\mathbf{A} \pm \mathbf{0 . 1 6 5}$ & $\mathbf{A} \pm \mathbf{0 . 6 2 9}$ & $\mathbf{B} \pm \mathbf{0 . 0 3 4}$ & $\mathbf{A} \pm \mathbf{0 . 1 8 7}$ & $\mathbf{A} \pm \mathbf{0 . 0 1 6}$ \\
\hline
\end{tabular}

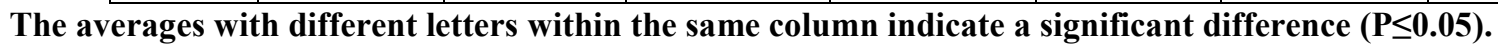

In general, molecular markers are among the important tools for knowing the genetic diversity among living organisms, which is the result of differences in the DNA sequence, which are characterized by their unaffected by environmental conditions or the age of the animal and their ease of use. SNPs are the insertion or deletion of segments of DNA of varying lengths from one to several thousand nucleotides. Variations in DNA can be classified as silent when they do not cause any change in the metabolic or phenotypic trait and therefore are not subject to selection, and on the contrary, they cause

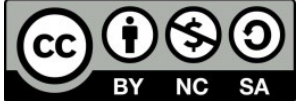

UTJagr This is an open access article under the CC-BY-NC-SA license (https://creativecommons.org/licenses/by-nc-sa/) 
functional differences when variations in the main nucleotides lead to a change in the sequence or coding of the amino acids of the protein and as a result new changes in function It may lead to an increase in metabolic efficiency, or the opposite may be a decrease in metabolism when compared to the wild or purebred type It may result in a loss of function or the acquisition of a new function, while mutations in the regulatory regions may affect the levels and patterns of gene expression, such as turning on or off genes, or overexpression in certain tissues, developmental stages, or different physiological stages (Hood and colleagues, 2004).

\section{The general averages of the traits studied}

From Table 4-13 it is clear that the general average of the characteristics of milk components in the studied Holstein cows was within the normal limits of this breed (Al-Qudsi, 2010), and their averages for the characteristics of the proportion of fat, protein, lactose and solid non-fatty materials were 3.43, 2.64, 3.95 and 7.42 Respectively, it is close to the results of the study of Ahmed (2020), Lazem (2020), and Al-Anbari (2003), and it is high in some of its characteristics compared to the study of Al-Abbasi (2012). As for the characteristics of milk density and the degree of freezing of milk, it was $26.62 \mathrm{~g} / \mathrm{cm} 3$ and -0.67 $\mathrm{m}$, which is close to the result of the milk density characteristic obtained by Ahmed (2020).

Table 5: General mean \pm standard error of characteristics of milk components in Holstein cows

\begin{tabular}{|c|c|c|c|}
\hline \multirow{2}{*}{} & Adjective & the number & General mean \pm standard error \\
\cline { 2 - 4 } & \multicolumn{3}{|c|}{ Milk ingredients characteristics } \\
\hline 1 & Fat percentage (\%) & 84 & $0.026 \pm 3.430$ \\
\hline 2 & Protein & 84 & $0.023 \pm 2.645$ \\
\hline 3 & percentage (\%) & 84 & $0.041 \pm 3.958$ \\
\hline 4 & Lactose (\%) & 84 & $0.083 \pm 7.422$ \\
\hline 5 & Non-fat solids & 84 & $0.322 \pm 26.628$ \\
\hline 6 & percentage (\%) & 84 & $0.014 \pm 0.677-$ \\
\hline
\end{tabular}

\section{References}

1. Al-Anbari, Nasr Nouri, Al-Rubaie, Abdul-Razzaq Laibi and Al-Khuzaie, Hamza Mazal. 2005. Effect of maternal heredity on some productive traits of Holstein cows. Iraqi Journal of Agricultural Sciences 47 (1) 375-381.

2. Brym, P. , Kaminski, S. , Wojcik,E. 2005. Polymorphism within the bovine prolactin receptor gene (PRLR). Animal Science Papers and Reports vol. 23 no. 1, 61-66.

3. Al-Khazraji, Sun Jassem and Hormuz, Hani Nasser. 2014. Study of the effect of some fixed environmental factors on milk production of Holstein cattle in Iraq. Iraqi Agricultural Research Journal 19 (1) 1-10 .

4. Alipanah,M. , Kalashnikova,L. \& Rodionov, G. 2007. Association of prolactin gene variants with milk production traits in Russian Red Pied cattle. IRANIAN JOURNAL of BIOTECHNOLOGY, Vol. 5. No. 3. 
5. Lü,Aw. , Hu,X. , Chen,H. , Jiang,J. ,Zhang,C. , Xu,H. \&Gao ,X. 2009. Single nucleotide polymorphisms in bovine $P R L$ gene and their associations with milk production traits in Chinese Holsteins. Molecular biology report 37. 547-551.

6. Hood,L. , Heath, J. R. , Phelps, M. E. \& Lin, B. 2004. Systems Biology and New Technologies Enable Predictive and Preventative Medicine. OCTOBER. VOL 306 SCIENCE www.sciencemag.org

7. Al-Qudsi, Nategh Hamid, and Elijah, Gil Victor. 2010. Dairy Cattle Production. Livestock department. College of Agriculture - University of Baghdad

8. Ahmed, Bashar Adham. 2020. The relationship of HSP70 gene genotype to productive and physiological performance of Holstein cows. PhD thesis. Baghdad University. Faculty of Agricultural Engineering Sciences.

9. Lazem, Howrah Ibrahim Sarhan. 2020. The relationship of genetic phenotypes in the IGF1 gene to productive performance in cows. Master Thesis. Baghdad University. Faculty of Agricultural Engineering Sciences. Animal Production. Animal breeding and improvement.

10. Al-Anbari, Nasr Nouri Khudair. 2003. Genetic evaluation of epiglottitis in Holstein cattle. PhD thesis. faculty of Agriculture. Baghdad University.

11. Abbasi, Imad Ghayeb. 2012. The effect of niacin and spraying with water under conditions of heat stress on the productive and physiological performance of Friesian cows in central Iraq. PhD thesis. faculty of Agriculture. Tikrit University. 